\title{
Pemanfaatan Teknologi Fingerprint Authentication untuk Otomatisasi Presensi Perkuliahan
}

\author{
Abdulloh Fakih", Indra Kharisma Raharjana ${ }^{2)}$, Badrus Zaman ${ }^{3)}$ \\ Program Studi Sistem Informasi, Fakultas Sains dan Teknologi, Universitas Airlangga \\ Kampus C Mulyorejo, Surabaya \\ ${ }^{1)}$ abdulloh-f-11@fst.unair.ac.id, \\ ${ }^{2) i n d r a . k h a r i s m a @ f s t . u n a i r . a c . i d ~}$ \\ ${ }^{3)}$ badruszaman@fst.unair.ac.id
}

\begin{abstract}
Abstrak - Dalam dunia pendidikan, daftar kehadiran atau presensi menjadi faktor penting yang tidak dapat dipisahkan dari kegiatan belajar mengajar dan evaluasi. Perguruan Tinggi biasanya menggunakan tanda tangan sebagai bukti kehadiran mahasiswa, sehingga data presensi kurang dapat dijamin validitasnya. Perlu dibangun sistem informasi presensi yang dapat memenuhi kebutuhan informasi dan meningkatkan keakuratan data. Penelitian ini bertujuan untuk menguji apakah sistem informasi presensi dengan memanfaatkan teknologi fingerprint authentication lebih baik dibandingkan dengan sistem presensi konvensional yang selama ini digunakan. Terdapat beberapa tahapan dalam penelitian ini. Tahap pertama adalah identifikasi kebutuhan menggunakan teknik wawancara, studi berkas, dan observasi. Tahap kedua adalah analisis kebutuhan untuk merumuskan solusi dari permasalahan yang ada. Tahap ketiga adalah perancangan sistem menggunakan activity diagram, class diagram, dan sequence diagram. Tahap keempat adalah pembangunan sistem menggunakan bahasa pemrograman Java, php dan database MySQL. Tahap kelima adalah pengujian sistem menggunakan functional testing dan acceptance testing. Tahap terakhir adalah evaluasi sistem dengan membandingkan sistem informasi presensi yang sudah dibangun dengan sistem presensi konvensional yang selama ini digunakan. Hasil dari evaluasi sistem menunjukkan bahwa sistem informasi presensi dengan memanfaatkan teknologi fingerprint authentication lebih baik dalam hal keakuratan data dan kemudahan manajemen presensi dibandingkan dengan sistem presensi konvensional yang selama ini digunakan.
\end{abstract}

Kata Kunci- Presensi, Fingerprint Authentication, Sistem Informasi

Abstract-The student's attendance is an important factor that can not be separated from the learning and evaluation activities. Higher Education usually using a signature as the proof of student attendance. However, the data validity using this method can not be guaranteed. An attendance information system can be used to to fulfil the required information and to improve data accuracy. This research aimed to test whether the attendance information system using fingerprint authentication technology is better than the existing conventional attendance system. There were several phases in this research. The first phase was the requirement identification using interviews, file analysis, and the observation techniques. The second phase was the requirement analysis to formulate solutions of existing problems. The third phase was to design a system using activity diagrams, class diagrams, and sequence diagrams. The fourth phase was the development of a system using Java, PHP and MySQL database. The fifth phase was to test the system using functional testing and acceptance testing. The last step was the evaluation of the system by comparing the attendance information system and the existing conventional attendance system. Results of the evaluation system shows that attendance information system using fingerprint authentication technology is better in terms of data accuracy and attendance management than the conventional attendance system.

Keywords-Attendance, Fingerprint Authentication, Information System

\section{PENDAHULUAN}

Presensi merupakan faktor penting yang tidak dapat dipisahkan dari kegiatan belajar mengajar dan evaluasi. Perguruan Tinggi biasanya menggunakan sistem presensi yang memanfaatkan tanda tangan sebagai bukti kehadiran mahasiswa. Data presensi tersebut dapat digunakan sebagai acuan untuk menentukan apakah mahasiswa tersebut dapat mengikuti ujian atau tidak, dapat juga dapat digunakan oleh dosen sebagai bahan pertimbangan dalam pemberian nilai mahasiswa serta sebagai bahan evaluasi keberhasilan kegiatan belajar mengajar.
Penerapan sistem presensi perkuliahan yang menggunakan tanda tangan sebagai bukti kehadiran mahasiswa, memberikan celah kepada mahasiswa untuk berbuat curang dalam pengisian daftar kehadiran atau presensi. Sebagai contoh ada mahasiswa yang tidak hadir dalam perkuliahan, namun di dalam daftar presensi mahasiswa tersebut tercatat hadir dalam perkuliahan. Kejadian tersebut sering dijumpai dalam kegiatan perkuliahan, sehingga data presensi tidak dapat dijamin validitasnya.

Selain dari sisi mahasiswa, masalah juga sering timbul dari sisi dosen dan pegawai tata usaha. 
Dosen sering lupa dalam mengisi kartu kendali dan jarang memonitor kehadiran mahasiswa. Pegawai tata usaha mengalami kesulitan dalam validasi dan rekapitulasi data presensi karena jumlah data yang banyak.

Solusi yang dapat menyelesaikan permasalahan tersebut adalah dengan membangun sebuah sistem yang dapat mencegah terjadinya kecurangan dalam pengisian daftar presensi dan memudahkan manajemen presensi. Solusi yang ditawarkan akan diwujudkan dengan memanfaatkan teknologi fingerprint authentication yang terintegrasi dengan sistem informasi presensi. Fingerprint authentication merupakan salah satu teknologi biometric yang paling umum digunakan. Dengan digunakanya teknologi fingerprint authentication maka mahasiswa diharuskan berada pada saat perkuliahan berlangsung, karena sidik jari setiap individu bersifat unik sehingga berbeda satu dengan lainya dan bersifat tetap meskipun sidik jari akan sedikit berubah ketika terjadi luka atau memar, sidik jari akan muncul kembali seperti semula setelah jari sembuh (Maltoni, Maio, Jain, \& Prabhakar, 2009).

Sudah banyak terdapat penelitian yang membahas penggunaan fingerprint sebagai media otentikasi, diantaranya adalah: penelitian yang berkaitan dengan tiga teknik otentikasi. Perbedaan, keunggulan, dan kekurangan dari masing-masing teknik menyatakan bahwa teknik otentikasi berbasis teknologi biometric lebih aman, nyaman, dan lebih dapat diandalkan jika dibandingkan dengan teknik otentikasi yang lain (Khan \& Zahid, 2010). Selanjutnya, penelitian yang menganalisa penggunaan berbagai macam teknologi biometric untuk meningkatkan kehadiran pegawai, dalam penelitian tersebut menghasilkan kesimpulan bahwa teknologi fingerprint adalah yang terbaik diantara teknologi biometric yang lain (Muhtahir, Adeyinka, \& Kayode, 2013). Penelitian tentang penggunaan teknologi fingerprint authentication dalam sistem presensi menunjukkan bahwa penggunaan teknologi fingerprint authentication dapat menghilangkan kecurangan dalam proses presensi (Abilimi, Opoku-Mensah, \& Yeboah, 2013). Penelitian lain juga menyatakan bahwa penggunaan teknologi biometric sidik jari dapat membantu manajemen presensi menjadi lebih baik dan akurat (Rao \& Satoa, 2013). Penggunaan teknik otentikasi yang lebih modern juga tidak menutup kemungkinan terjadi masalah dalam pelaksanaanya mulai dari penggunaan teknik knowledge based (PIN atau password) dan token based (ID card, Passpor), ke-dua metode tersebut juga rentan dalam hal sekuritas misalnya saja PIN atau password yang bisa saja lupa atau dihack, ID card hilang, diduplikasi atau bahkan dicuri (Lourde \& Khosla, 2010).

\section{Metode PENELITIAN}

\section{A. Identifikasi Kebutuhan}

Identifikasi kebutuhan dilakukan untuk mendapatkan data dan informasi terkait kegiatan presensi. Teknik yang digunakan dalam identifikasi kebutuhan dalam penelitian ini adalah sebagai berikut:

1) Wawancara: Melakukan wawancara dengan pengguna sistem dalam hal ini adalah mahasiswa, dosen, dan pegawai tata usaha untuk memperoleh data dan informasi terkait kegiatan presensi yang selama ini digunakan.

2) Studi berkas : Mempelajari berkas-berkas yang terkait dengan sistem presensi yang selama ini digunakan.

3) Observasi: Melakukan observasi secara langsung untuk mengetahui prosedur-prosedur dalam kegiatan presensi.

\section{B. AnalisisKebutuhan}

Data yang telah terkumpul selanjutnya dianalisa dan kemudian merumuskan solusi untuk memecahkan permasalahan yang ada. Dalam tahap ini hal-hal yang perlu dianalisis adalah hambatan yang dialami, penggun sistem, dan fungsi yang ditangani sistem.

\section{Perancangan Sistem}

Pada tahapan perancangan sistem dilakukan dengan menggunakan metode berorientasi obyek dan digambarkan dalam bentuk diagram-diagram UML antara lain: activity diagram, class diagram, sequence diagram, dan ER diagram. Diagramdiagram tersebut digunakan sebagai acuan dalam pembangunan sistem.

\section{Pembangunan Sistem}

Pada tahapan pembangunan sistem hasil dari perancangan diimplementasikan dengan pengkodean program menggunakan dua bahasa pemrograman yang berbeda, aplikasi fingerprint reader akan menggunakan JAVA sedangkan aplikasi manajemen presensi akan menggunakan PHP, kedua aplikasi tersebut akan menggunakan DBMS yang sama yaitu MySQL. Hasil dari tahapan pembangunan sistem adalah sebuah aplikasi yang dapat dijalankan.

\section{E. Pengujian Sistem}

Pada tahapan pengujian sistem, pengujian dilakukan dengan functional testing dan acceptance testing untuk menguji fungsionalitas dan kelayakan dari sistem. Pada functional testing berbagai macam kombinasi inputan diuji apakah hasil yang didapat sesuai dengan output yang diharapkan. Sedangkan dalam acceptance testing kriteria-kriteria pengujian dipilih terlebih dahulu, kriteria tersebut antara lain: functional correctness 
and completeness, dan usability. acceptance testing akan dilakukan dengan melakukan simulasikan terlebih dahulu pada kelas praktikum D3 Sistem Informasi Universitas Airlangga, kemudian dosen, mahasiswa, dan tata usaha yang terlibat diminta untuk mengisi quisioner terkait persepsi penerimaan terhadap sistem tersebut setelah mencobanya. Functional correctness and completeness berkaitan dengan apakah sistem yang dibuat sudah benar dan sudah memenuhi kebutuhan pengguna, sedangkan usability berkaitan dengan apakah sistem dapat digunakan dengan mudah atau tidak dan apakah sistem dapat membantu menyelesaikan masalah (Naik \& Tripathy, 2011). Hasil dari tahapan ini adalah berupa test case dan kuesioner.

\section{F. Evaluasi Sistem}

Tahapan terakhir dalam penelitian ini adalah evaluasi sistem informasi presensi yang sudah dibangun dengan cara membandingkan antara sistem presensi yang baru dengan sistem presensi konvensional yang selama ini digunakan. Perbandingan didapatkan dari timbal balik/feedback hasil simulasi oleh pengguna dalam hal ini adalah mahasiswa, dosen, dan pegawai tata usaha. Simulasi dilakukan berdasarkan skenario pengujian yang telah dibuat. Kuesioner digunakan untuk mengetahui bagaimana respon pengguna setelah melakukan simulasi. Evaluasi dilakukan untuk menilai apakah sistem informasi presensi yang baru dapat menyelesaikan permasalahanpermasalahan yang muncul pada sistem presensi konvensional yang selama ini digunakan.

\section{HASIL DAN PEMBAHASAN}

\section{A. Hasil Identifikasi Kebutuhan}

Identifikasi kebutuhan dilakukan dengan beberapa tekinik yaitu wawancara, studi berkas dan observasi. berikut adalah hasil dari tahapan identifikasi kebutuhan:

1) Wawancara: Hasil wawancara adalah berupa outline wawancara yang berisi informasi terkait hambatan dan prosedur kegiatan presensi. Ditemukan fakta bahwa resiko mahasiswa melakukan kecurangan absensi seperti titip absen masih terbuka luas ketika menggunakan sistem presensi tanda tangan. Permasalahan lain yang sering muncul adalah kelalaian mahasiswa dalam mengisi absensi perkuliahan karena daftar presensi diisi bergantian pada saat perkuliahan berlangsung. Permasalahan yang dialami dosen diantaranya adalah dosen lupa mengisi kartu kendali dan memantau kehadiran mahasiswa, sehingga mahasiswa sering melakukan kecurangan saat mengisi daftar presensi. Permasalahan yang dialami pegawai tata usaha adalah proses validasi dan rekapitulasi data presensi yang memakan waktu lama. Data presensi masih manual yaitu berupa print out, sehingga daftar kehadiran dan kartu kendali sering hilang. Surat keterangan sakit/ijin mahasiswa yang terselip dalam buku presensi juga rentan hilang.

2) Studi berkas: Hasil studi berkas berupa informasi terkait dokumen-dokumen yang terlibat di dalam proses presensi, diantaranya adalah: format daftar presensi mahasiswa, format kartu kendali dosen, dan daftar cekal. Dokumen-dokumen tersebut digunakan sebagai acuan dalam pembangunan database

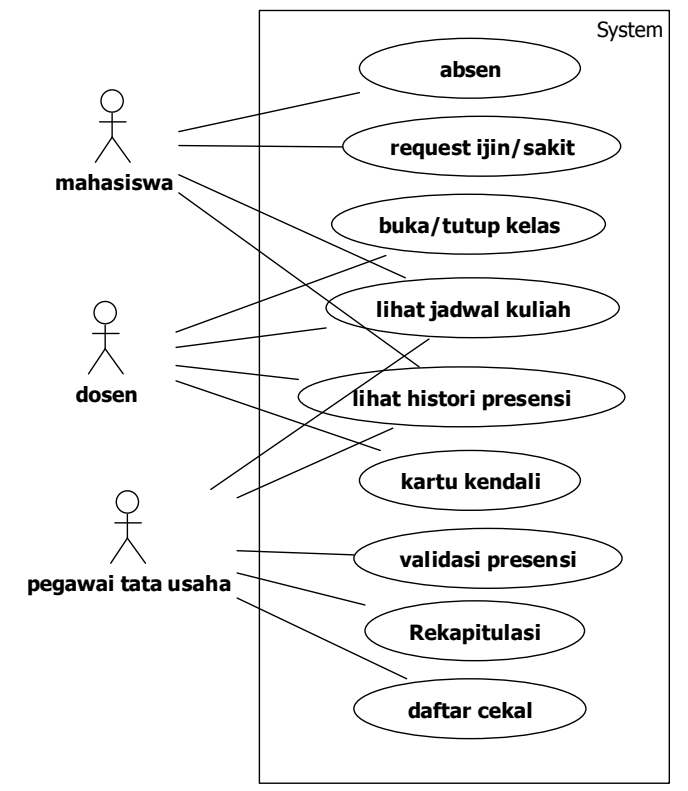

Gambar 1. Use case diagram sistem informasi presensi

3) Observasi: hasil dari observasi secara langsung berupa informasi terkait prosedurprosedur dalam kegiatan presensi. Prosedurprosedur tersebut antara lain: Sebelum perkuliahan dimulai dosen mengambil buku presensi yang berisi print out daftar presensi mahasiswa dan kartu kendali dosen di ruang TU, Pada saat perkuliahan sedang berlangsung buku presensi diberikan kepada mahasiswa untuk diisi secara bergantian, di akhir perkuliahan dosen mengisi kartu kendali. Setelah kartu kendali diisi oleh dosen, perwakilan mahasiswa yang bertanggung jawab pada mata kuliah yang berlangsung mengecek apakah materi perkuliahan sudah berjalan sesuai kontrak atau tidak. Setelah perkuliahan berakhir, buku presensi dikembalikan kepada pegawai tata usaha. Ketika mahasiswa tidak dapat mengikuti perkuliahan karena sakit atau ijin, mahasiswa wajib memberikan surat 
keterangan sakit atau ijin yang jelas. Surat tersebut diselipkan dalam buku presensi atau dapat langsung diberikan kepada pegawai tata usaha. Pegawai tata usaha secara berkala memeriksa surat yang ada dalam buku presensi dan melakukan kegiatan rekapitulasi serta input data presensi ke dalam sistem cyber campus.

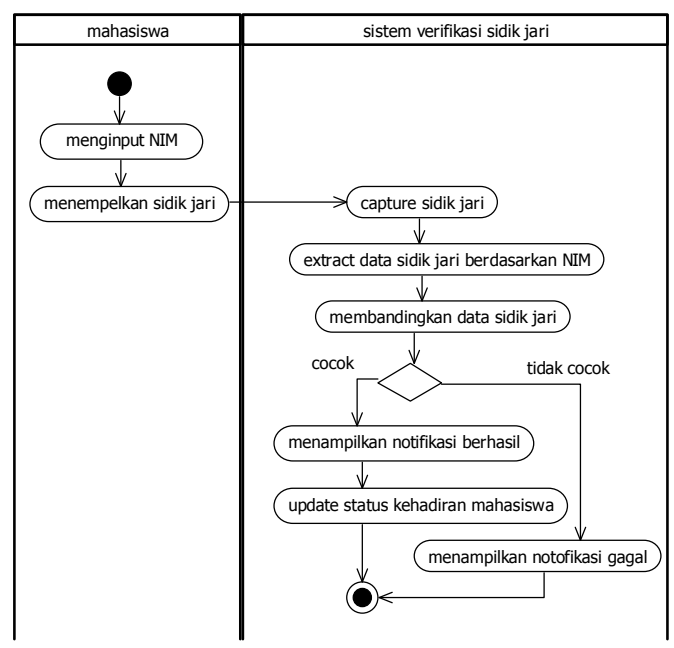

Gambar 2. Activity diagram verifikasi sidik jari

\section{B. Hasil Analisis Kebutuhan}

Data dan informasi yang diperoleh dari proses idntifikasi kebutuhan selanjutnya dianalisis. Hasil dari analisis kebutuhan adalah sebagai berikut:

1) Fitur yang dibutuhkan: Berdasarkan hambatan yang dialami pada sistem presensi yang selama ini digunakan, maka sistem informasi presensi memiliki fitur yang digambarkan dengan use case diagram pada gambar 1 .

2) Prosedur baru: berdasarkan fitur yang sudah didefinisikan, prosedur atau urutan kegiatan presensi mengalami beberapa perubahan. Prosedur proses presensi yang baru adalah sebagai berikut:

a) Mahasiswa melakukan proses verifikasi sidik jari terlebih dahulu sebelum perkuliahan dimulai. Setelah proses verifikasi selesai, mahasiswa dapat melakukan kegiatan presensi dengan login kedalam sistem. Mahasiswa tidak akan bisa login sebelum mereka melakukan proses verifikasi sidik jari terlebih dahulu. Setelah login kedalam sistem, mahasiswa tidak bisa bisa langsung melakukan presensi sebelum dosen membuka mata kuliah melalui sistem.

b) Dosen membuka kelas terlebih dahulu agar mahasiswa yang sudah hadir dalam kelas dapat melakukan kegiatan presensi, ketika dosen sudah kelas, mahasiswa tidak akan bisa melakukan kegiatan presensi meskipun mereka dapat login kedalam sistem. Proses membuka dan menutup kelas tersebut dilakukan sesuai dengan kehendak dosen atau sesuai dengan kontrak kuliah yang telah disetujui oleh mahasiswa. Sehingga mahasiswa yang datang lebih dari kesepakatan kontrak mengenai batas keterlambatan tidak akan bisa melakukan proses presensi. Proses pengisian kartu kendali dilakukan oleh dosen melalui sistem.

c) Ketika mahasiwa berhalangan hadir dalam kegiatan prekuliahan, mahasiwa dapat melakukan request ijin/sakit melalui sistem untuk kemudian divalidasi oleh pegawai tata usaha. Request ijin/sakit tersebut harus jelas dengan menunjukkan surat keterangan dokter bagi yang sakit atau surat ijin.

d) Proses rekapitulasi presensi dan penentuan daftar cekal dilakukan secara otomatis oleh sistem, mahasiswa dengan tingkat kehadiran kurang dari 75\% akan secara otomatis tercekal.

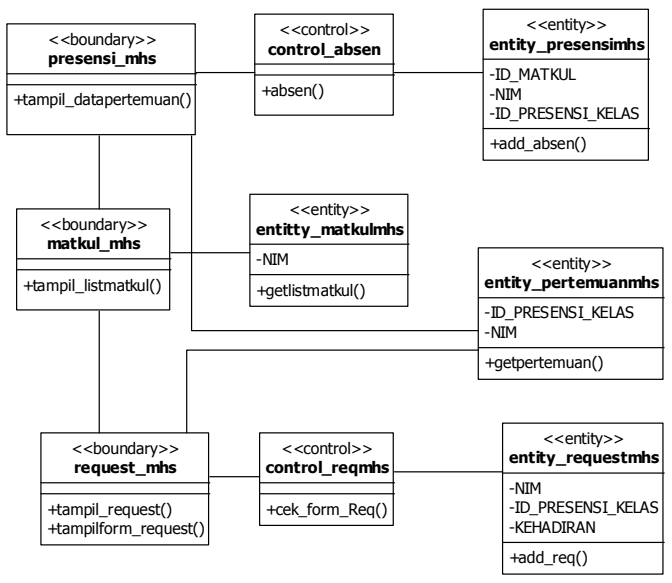

Gambar 3. Class diagram mahasiswa

\section{Hasil Perancangan Sistem}

Hasil perancangan sistem berupa diagram sebagai berikut:

1) Activity diagram: Activity diagram dibuat berdasarkan fitur atau fungsi-fungsi yang sudah digambarkan dalam use case diagram (Pressman, 2010). Sebagai contoh activity diagram verifikasi sidik jari yang dibuat berdasarkan fitur absen dapat dilihat pada gambar 2.

2) Class diagram: Class diagram menggambarkan kelas-kelas yang digunakan dalam sistem informasi presensi. Sebagai contoh class diagram untuk mahasiswa dapat dilihat pada gambar 3 . 


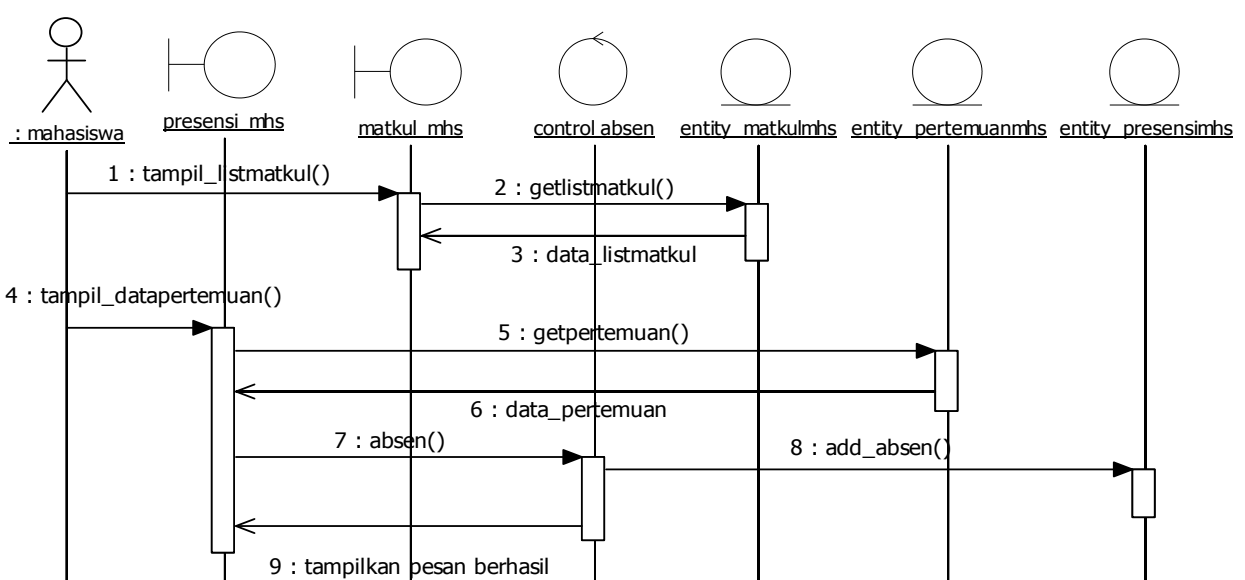

Gambar 4. Sequence diagram absen

3) Sequence diagram: Sequence diagram dibuat berdasarkan class diagram dan activity diagram. Sequence diagram menggambarkan interaksi dan aliran pesan antar kelas yang sudah didefinisikan pada class diagram. Sebagai contoh sequence diagram absen dapat dilihat pada gambar 4 .

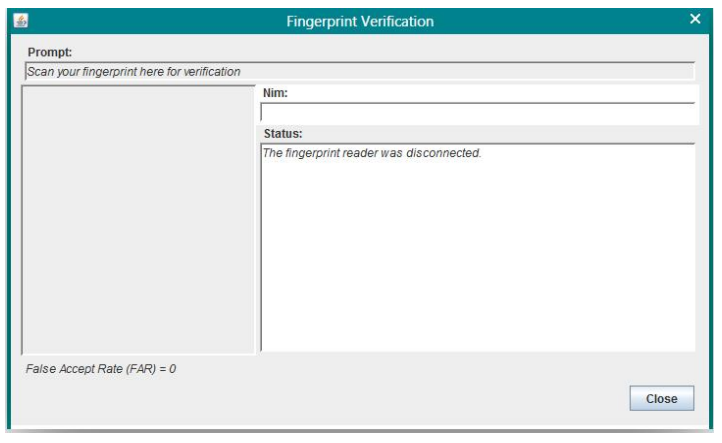

Gambar 5. Antarmuka aplikasi fingerprint reader

4) ER diagram: Desain database sistem informasi presensi digambarkan dalam bentuk locgical model dengan menggunakan conceptual data model (CDM). CDM yang telah dibuat kemudian diubah menjadi physical data model (PDM) dengan mengenerate CDM yang sudah dibuat melalui tools power designer. Selanjutnya
PDM digenerate menjadi SQL script yang digunakan untuk membangun database.

\section{Hasil Pembangunan Sistem}

Pada tahap pembangunan sistem, hasil dari perancangan sistem diimplementasikan dalam bentuk source code program. Hasil dari tahap pembangunans sistem berupa program yang dapat dijalankan. Sistem informasi presensi yang dibangun terdiri dari dua aplikasi, yaitu: aplikasi fingerprint dan aplikasi manajemen presensi. Kedua aplikasi tersebut menggunakan DBMS yang sama yaitu MySQL.

1) Pembangunan aplikasi fingerprint reader: Aplikasi fingerprint reader dibangun menggunakan bahasa pemrograman JAVA dengan memanfaatkan SDK dari fingerprint. Java database connection API (JDBC) digunakan Untuk mrnghubungkan aplikasi fingerprint reaeder dengan database MySQL. Antarmuka aplikasi fingerprint reader dapat dilihat pada gambar 5 .

2) Pembangunan aplikasi manajemen presensi: Aplikasi manajemen presensi dibangun dengan menggunakan bahasa pemrograman PHP dan menggunakan database yang sama dengan aplikasi fingerprint reader yaitu MySQL. Kerangka aplikasi dibuat

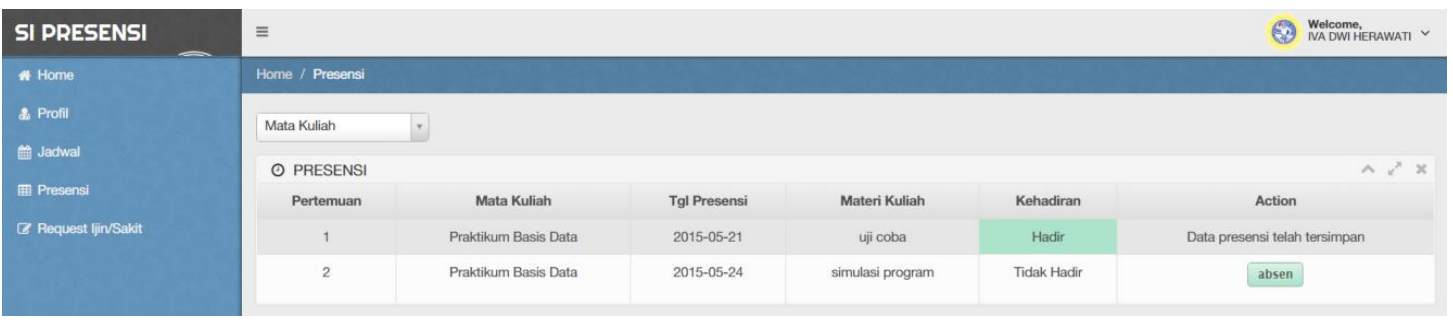

Gambar 6. Antarmuka aplikasi manajemen presensi 


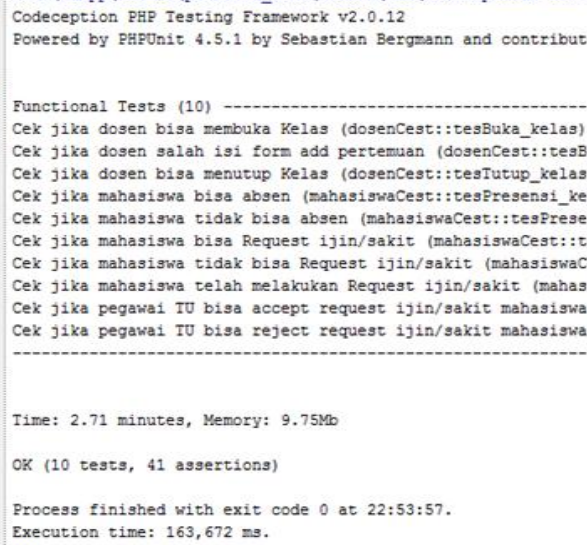

Gambar 7. Hasil automated test

berdasarkan class diagram yang sudah didefinisikan sebelumnya. Setiap class dibangun berdasarkan jenis dari masingmasing class. Antarmuka aplikasi manajemen presensi dapat dilihat pada gambar 6

\section{E. Hasil Pengujian Sistem}

Pengujian yang dilakukan terdiri dari dua macam yaitu: functional testing dan acceptance testing. Functional testing dilakukan dengan metode blackbox testing, sedangkan acceptance testing dilakukan dengan melakukan simulasi pengunaan sistem terlebih dahulu di laboratorium komputer Sistem Informasi Universitas Airlangga dengan melibatkan dosen, mahasiswa dan tata usaha. Penguna diminta untuk mengisi quisioner terkait penerimaan pengguna jika sistem ini diimplementasikan. Berikut ini penjabaran dari masing-masing testing yang telah dilakukan :

1) Functional testing: Functional testing dilakukan untuk menguji fungsionalitas program yang sudah dibangun. Berbagai macam kombinasi input diuji untuk mengetahui apakah hasil yang didapat telah sesuai dengan hasil yang diharapkan. Dalam penelitian ini functional testing dilakukan secara otomatis (automated test) dengan menggunakan framework codeception. Penulisan test case pada codeception bersifat deskriptif dan didasarkan pada bagaimana sistem berinteraksi dengan pengguna (behavioralsystem). Contoh source code test case dapat dilihat pada listing 1 .Sebanyak 10 test case diuji dan berhasil dilakukan dengan hasil sesuai output yang diharapkan. Hasil automated test dapat dilihat pada gambar 7 .

2) Acceptance testing: Acceptance testing dilakukan dengan cara simulasi program secara langsung. Kriteria penerimaan program ditentukan terlebih dahulu, dalam penelitian ini kriteria yang diujikan adalah functional correcteness and completeness dan usabaility. Simulasi dilakukan secara langsung ketika perkuliahan berlangsung dengan jumlah responden sebanyak 17 orang yang terdiri dari: 14 perwakilan mahasiswa, 2 dosen, dan 1 pegawai tata usaha. Hasil dari acceptance testing berupa rekapitulasi hasil pengisian kuisoner yang dapat dilihat pada tabel 1 dan tabel 2.

public function tesPresensi_kelasBuka(FunctionalTester \$I) \{

\$I->am("Developer");

\$I->wantTo("Cek jika mahasiswa bisa absen");

\$I->lookForwardTo("Perform Absen");

\$this->login_succes $(\$ 1)$;

\$I->click('Presensi');

\$I->seeInCurrentUrl('/presensi_mhs.php');

\$I->selectOption('matkul','presensi_mhs.php?idmatkul=SID011 \&nim=151411513001');

\$I- $>$ amOnPage('presensi_mhs.php?idmatkul=SID011\&nim= 151411513001 ');

\$I->see('Praktikum Basis Data', 'td');

\$I->click('absen');

$\$$ I->see('Absen berhasil !');

Listing 1. Test case tesPresensi_kelasBuka

\section{F. Hasil Evaluasi Sistem}

Evaluasi sistem dilakukan dengan membandingkan sistem presensi yang selama ini digunakan dengan sistem informasi presensi yang dibangun. Sistem presensi yang selama ini digunakan memiliki beberapa kekurangan seperti yang sudah dibahas pada tahap analisis sebelumnya. Jika selama ini data presensi yang bersifat manual yaitu berupa print out bukti kehadiran yang kemudian dimasukkan kedalam sistem cybercampus, dengan digunakanya sistem yang baru memungkinkan integrasi dengan cybercampus tanpa memasukkan kembali karena database dari sistem informasi presensi dibuat berdasarkan model database cybercampus.

Berdasarkan hasil pengujian menggunakan functional testing dan acceptance testing dapat disimpulkan bahwa seluruh fitur pada sistem informasi presensi telah berjalan dengan baik dan benar, dan dapat diterima oleh pengguna. Jika dibandingkan dengan sistem presensi 
konvensional yang selama ini digunakan, sistem informasi presensi dinilai dapat:

1) Mencegah mahasiswa melakukan kecurangan dalam pengisian absen (titip absen)

TABEL 1. HASIL PENGISIAN KUISONER BAGIAN 1

\begin{tabular}{|c|c|c|c|}
\hline \multicolumn{4}{|c|}{ Bagian 1 : Functional Correctness and Completeness } \\
\hline \multirow{2}{*}{ No } & \multirow{2}{*}{ Pertanyaan } & \multicolumn{2}{|c|}{ Jumlah } \\
\hline & & Ya & Tidak \\
\hline \multicolumn{4}{|c|}{ Mahasiswa } \\
\hline 1 & $\begin{array}{l}\text { Fitur login dengan memanfaatkan } \\
\text { fingerprint authentication pada } \\
\text { Sistem Informasi Presensi berjalan } \\
\text { dengan baik dan benar? }\end{array}$ & 14 & 0 \\
\hline 2 & $\begin{array}{l}\text { Fitur absen pada Sistem Informasi } \\
\text { Presensi berjalan dengan baik dan } \\
\text { benar? }\end{array}$ & 14 & 0 \\
\hline 3 & $\begin{array}{l}\text { Fitur request ijin/sakit pada Sistem } \\
\text { Informasi Presensi berjalan dengan } \\
\text { baik dan benar? }\end{array}$ & 14 & 0 \\
\hline 4 & $\begin{array}{l}\text { Fitur jadwal kuliah pada Sistem } \\
\text { Informasi Presensi berjalan dengan } \\
\text { baik dan benar? }\end{array}$ & 14 & 0 \\
\hline 5 & $\begin{array}{l}\text { Fitur histori presensi pada Sistem } \\
\text { Informasi Presensi berjalan dengan } \\
\text { baik dan benar? }\end{array}$ & 14 & 0 \\
\hline \multicolumn{4}{|c|}{ Dosen } \\
\hline 1 & $\begin{array}{l}\text { Fitur buka/tutup kelas pada Sistem } \\
\text { Informasi Presensi berjalan dengan } \\
\text { baik dan benar? }\end{array}$ & 2 & 0 \\
\hline 2 & $\begin{array}{l}\text { Fitur kartu kendali pada Sistem } \\
\text { Informasi Presensi berjalan dengan } \\
\text { baik dan benar? }\end{array}$ & 2 & 0 \\
\hline 3 & $\begin{array}{l}\text { Fitur jadwal kuliah pada Sistem } \\
\text { Informasi Presensi berjalan dengan } \\
\text { baik dan benar? }\end{array}$ & 2 & 0 \\
\hline 4 & $\begin{array}{l}\text { Fitur histori presensi pada Sistem } \\
\text { Informasi Presensi berjalan dengan } \\
\text { baik dan benar? }\end{array}$ & 2 & 0 \\
\hline \multicolumn{4}{|c|}{ Pegawai Tata Usaha } \\
\hline 1 & $\begin{array}{l}\text { Fitur histori dan validasi Presensi } \\
\text { pada Sistem Informasi Presensi } \\
\text { berjalan dengan baik dan benar? }\end{array}$ & 1 & 0 \\
\hline 2 & $\begin{array}{l}\text { Fitur daftar cekal pada pada Sistem } \\
\text { Informasi Presensi berjalan dengan } \\
\text { baik dan benar? }\end{array}$ & 1 & 0 \\
\hline 3 & $\begin{array}{l}\text { Fitur validasi Request Ijin/Sakit } \\
\text { pada Sistem Informasi Presensi } \\
\text { berjalan dengan baik dan benar? }\end{array}$ & 1 & 0 \\
\hline 4 & $\begin{array}{l}\text { Fitur jadwal kuliah pada Sistem } \\
\text { Informasi Presensi berjalan dengan } \\
\text { baik dan benar? }\end{array}$ & 1 & 0 \\
\hline \multirow{3}{*}{\multicolumn{2}{|c|}{$\begin{array}{r}\text { total jawaban } \\
\text { total pertanyaan } \\
\text { presentase }\end{array}$}} & 82 & 0 \\
\hline & & \multicolumn{2}{|c|}{82} \\
\hline & & $100 \%$ & $0 \%$ \\
\hline
\end{tabular}

2) Mencegah hilangnya surat ijin/sakit dan daftar presensi mahasiswa

3) Mencegah lupa dalam mengisi kartu kendali dosen

4) Mempermudah dosen dalam memantau kehadiran mahasiswa

5) Mempermudah proses validasi dan rekapitulasi data presensi

Ada beberapa saran yang diberikan oleh responden terhadap sistem informasi presensi, secara garis besar dapat dikelompokkan menjadi dua yaitu: saran yang bersifat teknis dan non teknis.

TABEL 2. HASIL PENGISIAN KUISONER BAGIAN 2

\begin{tabular}{|c|c|c|c|}
\hline \multicolumn{4}{|c|}{ Bagian 2 : Usability } \\
\hline \multirow{2}{*}{ No } & \multirow{2}{*}{ Pernyataan } & \multicolumn{2}{|c|}{ Jumlah } \\
\hline & & Setuju & Tidak \\
\hline \multicolumn{4}{|c|}{ Mahasiswa } \\
\hline 1 & $\begin{array}{l}\text { Informasi yang ditampilkan pada } \\
\text { Sistem Infomasi Presensi jelas dan } \\
\text { mudah dimengerti }\end{array}$ & 14 & 0 \\
\hline 2 & $\begin{array}{l}\text { Sistem Informasi Presensi dapat } \\
\text { mempermudah mahasiswa dalam } \\
\text { melakukan kegiatan presensi di } \\
\text { kelas }\end{array}$ & 14 & 0 \\
\hline 3 & $\begin{array}{l}\text { Sistem Informasi Presensi dapat } \\
\text { meningkatkan keakuratan data } \\
\text { presensi (mencegah kegiatan titip } \\
\text { absen) }\end{array}$ & 14 & 0 \\
\hline 4 & $\begin{array}{l}\text { Sistem Informasi Presensi dapat } \\
\text { mempermudah proses ijin/sakit }\end{array}$ & 14 & 0 \\
\hline \multicolumn{4}{|c|}{ Dosen } \\
\hline 1 & $\begin{array}{l}\text { Informasi yang ditampilkan pada } \\
\text { Sistem Infomasi Presensi jelas dan } \\
\text { mudah dimengerti }\end{array}$ & 2 & 0 \\
\hline 2 & $\begin{array}{l}\text { Sistem Informasi Presensi dapat } \\
\text { meningkatkan keakuratan data } \\
\text { presensi (mencegah kegiatan titip } \\
\text { absen) }\end{array}$ & 2 & 0 \\
\hline 3 & $\begin{array}{l}\text { Sistem Informasi Presensi dapat } \\
\text { mempermudah proses pengisian } \\
\text { kartu kendali dosen (mencegah lupa } \\
\text { dalam mengisi kartu kendali dosen) }\end{array}$ & 2 & 0 \\
\hline 4 & $\begin{array}{l}\text { Sistem Informasi Presensi dapat } \\
\text { mempermudah dosen dalam melihat } \\
\text { histori presensi dan daftar kehadiran } \\
\text { mahasiswa }\end{array}$ & 2 & 0 \\
\hline \multicolumn{4}{|c|}{ Pegawai Tata Usaha } \\
\hline 1 & $\begin{array}{l}\text { Informasi yang ditampilkan pada } \\
\text { Sistem Infomasi Presensi jelas dan } \\
\text { mudah dimengerti }\end{array}$ & 1 & 0 \\
\hline 2 & $\begin{array}{l}\text { Sistem Informasi Presensi dapat } \\
\text { meningkatkan keakuratan data } \\
\text { presensi }\end{array}$ & 1 & 0 \\
\hline 3 & $\begin{array}{l}\text { Sistem Informasi Presensi dapat } \\
\text { mempermudah proses validasi } \\
\text { kehadiran mahasiswa }\end{array}$ & 1 & 0 \\
\hline 4 & $\begin{array}{l}\text { Sistem Informasi Presensi dapat } \\
\text { mempermudah proses penentuan } \\
\text { daftar cekal }\end{array}$ & 1 & 0 \\
\hline 5 & $\begin{array}{l}\text { Sistem Informasi Presensi dapat } \\
\text { mempermudah proses rekapitulasi }\end{array}$ & 1 & 0 \\
\hline 6 & $\begin{array}{l}\text { Sistem Informasi Presensi dapat } \\
\text { mempercepat proses presensi }\end{array}$ & 1 & 0 \\
\hline \multirow{3}{*}{\multicolumn{2}{|c|}{$\begin{array}{r}\text { total jawaban } \\
\text { total pernyataan } \\
\text { presentase }\end{array}$}} & 70 & 0 \\
\hline & & \multicolumn{2}{|c|}{70} \\
\hline & & $100 \%$ & $0 \%$ \\
\hline
\end{tabular}

1) Saran teknis: perlu dilakukan penyesuaian beberapa fitur seperti: dosen tidak dapat mengganti status kelas ketika melebihi jam mata kuliah dan pegawai tata usaha dapat mengganti data jadwal perkuliahan serta penambahan fitur panduan/petunjuk penggunaan sistem. 
2) Saran non teknis: harus disediakan sarana dan prasarana atau infrastruktur yang memadai untuk menerapkan sistem informasi presensi.

\section{KESIMPULAN}

Penelitian ini memiliki hipotesis bahwa pengaplikasian presensi mengunakan fingerprint authentication akan memudahkan otomatisasi pencatatan presensi dibandingkan dengan sistem konvensional yang validasinya mengunakan tanda tangan. Berdasarkan hasil evaluasi sistem, dapat disimpulkan bahwa sistem informasi presensi lebih baik dalam hal keakuratan data dan kemudahan manajemen presensi jika dibandingkan dengan sistem presensi konvensional yang selama ini digunakan.

Sistem mampu memberikan solusi terhadap permasalahan-permasalahan yang terjadi pada sistem presensi konvensional yang selama ini digunakan seperti: mencegah mahasiswa melakukan kecurangan dalam pengisian absen (titip absen), mencegah hilangnya surat ijin/sakit dan daftar presensi mahasiswa, mencegah lupa dalam mengisi kartu kendali dosen, mempermudah dosen dalam memantau kehadiran mahasiswa, dan mempermudah proses validasi dan rekapitulasi data presensi

Untuk pengembangan selanjutnya perlu dipertimbangkan untuk menerapkan mekanisme absen fingerprint baru agar dapat digunakan di dalam kelas teori tanpa harus mengakses komputer, misalnya menggabungkannya dengan smartcard sehingga presensi dikelas jadi lebih ringkas dan cepat.

\section{DAFTAR PUSTAKA}

Abilimi, C. A., Opoku-Mensah, E., \& Yeboah, T. (2013). Automatic Biometric Student ttendance System: A Case Study Christian Service University College. Journal of Engineering, Computers \& Applied Sciences , 2 (6), 117-122.

Khan, H. Z., \& Zahid, H. (2010). Comparative study of authentication techniques. International Journal of Video \& Image Processing and Network Security IJVIPNS , 10 (4), 9-13.

Lourde, M. R., \& Khosla, D. (2010). Fingerprint identification in biometric security systems. International Journal of Computer and Electrical Engineering , 2 (5), 852-855.

Maltoni, D., Maio, D., Jain, A. K., \& Prabhakar, S. (2009). Handbook of fingerprint recognition. London: Springer-Verlag.

Muhtahir, O., Adeyinka, A., \& Kayode, A. (2013). Fingerprint Biometric Authentication for Enhancing Staff Attendance System. International Journal of Applied Information Systems , 5 (3), 19-24.

Naik, K., \& Tripathy, P. (2011). Software testing and quality assurance: theory and practice. USA: John Wiley \& Sons.

Pressman, R. (2010). Software Engineering: A Practitioner's Approach, 7th ed. New York: Hill Higher Education.

Rao, S., \& Satoa, K. J. (2013). An Attendance Monitoring Sistem Using Biometrics Authentication. International Journal of Advanced Research in Computer Science and Software Engineering , 3 (4), 379-383. 